\title{
PENGGUNAAN BAJU ANT-VGAR UNTUK RASA NYAMAN PASIEN PADA PEMERIKSAAN ELEKTROKARDIOGRAM (EKG)
}

\author{
Yunani, Tegar Wisnu Prasetyo, Amrih Widiati, Widiyaningsih \\ STIKes Karya Husada Semarang, Jl. Kompol R Soekanto No 46 Semarang \\ Email:yunani.sururi@gmail.com
}

\begin{abstract}
ABSTRAK
Elektrokardiogram (EKG) merupakan suatu sinyal yang terbentuk sebagai hasil dari aktivitas listrik jantung, sinyal ekg mempunyai bentuk spesifik sehingga dapat dijadikan sebagai acuan untuk menentukan kondisi kesehatan jantung. Pemeriksaan EKG pasien diharuskan membuka baju, di mana hal ini mengakibatkan pasien kurang nyaman. Hasil wawancara terhadap pasien yang akan dilakukan EKG, semua responden mengalami rasa malu atau kurang nyaman ketika pemasangan EKG terutama pasien perempuan karena daerah dada dibuka. Salah satu tindakan untuk meningkatkan rasa nyaman dengan menggunakan baju ANT-VGAR yang digunakan untuk menutupi area dada pasien. Penelitian ini bertujuan untuk mengetahui pengaruh baju ANT-VGAR terhadap rasa nyaman pasien pada pemeriksaan EKG. Penelitian ini menggunakan desain quasy exsperimen dengan pendekatan intact group comparison. Sampel penelitian ini adalah pasien yang akan dilakukan pemeriksaan EKG dengan teknik purposive sampling sebanyak 30 respondenyang dibagi dua kelompok, 15 responden kelompok intervensi dan 15 responden kelompok kontrol. Instrumen yang digunakan adalah Standar prosedur Operasional (SPO) baju ANT-VGAR dan kuesioner rasa nyaman untuk mengukur kenyamanan responden saat pemeriksaan EKG. Hasil penelitian didapatkan nilai rerata rasa nyaman pasien pada kelompok intervensi 22,53 dan pada kelompok kontrol 19,86. Hasil uji Man Whitney didapatkan perbedaan yang signifikan rerata rasa nyaman pada kelompok kontrol dan kelompok intervensi dengan p-value $(0,023)$. Baju ANT-VGAR meningkatkan rasa nyaman pasien pada pemeriksaan EKG.
\end{abstract}

Kata Kunci : rasa nyaman; baju ANT-VGAR; pemeriksaan EKG

\section{ANT-VGAR CLOTHING FOR PATIENTS' COMFORT ON ELECTROCARDIOGRAM EXAMINATION}

\begin{abstract}
Electrocardiogram (ECG) is a signal that is formed as a result of electrical activity of the heart; ECG signal has a specific shape so that it can be used as a reference to determine the condition of heart health. ECG examination requires the patient to undress that's causing the patient feel less comfortable. The results of interviews with the patients who would have an ECG examination showed that all respondents feel embarrassed or uncomfortable when installing an ECG, especially female patients because the chest area is opened. Using ANT-VGA cloth to cover chest area was an effort to reducing uncomfort feeling for patients. The aim of this study was to determine the effect of ANT-VGAR clothing on the comfort of the patient during the examination. This study usedquasy exsperiment with an intact group comparison approach. The respondents usedin this research were the patients ofECG examination with purposive sampling. A total of 30 respondents were divided into two groups, 15 respondents in the intervention group and 15 respondents in the control group. The instrument used was the Standart Operational Prosedure(SOP) ANT-VGAR shirt used during the ECG examination and a comfort questionnaire to measure the respondents' comfort during the ECG examination. The mean value of comfort in the intervention group was 22.53 and in the control group were 19.86. Whitney Man test results obtained significant differences in the average comfort in the control group and the intervention group with $p$-value $(0.023)$. The results of this study concluded that there is an influence of the ANT-VGAR shirt on the comfort of the patient during the ECG examination.
\end{abstract}

Keywords: patient comfort; ANT-VGAR shirt; ECG examination

Jurnal SMART Keperawatan is licensed under a Creative Commons Attribution-ShareAlike 4.0 International License. 


\section{LATAR BELAKANG}

Penyakit jantung merupakan penyakit tidak menular yang semakin hari semakin bertambah. Data World Health Organization (WHO) tahun 2018 menyebutkan lebih dari 17 juta orang meninggal dunia akibat penyakit jantung dan pembuluh darah, atau sekitar 31\% dari seluruh kematian di dunia, sebagian besar atau sekitar 8,7 juta disebabkan oleh penyakit jantung. Data lainnya menunjukkan lebih dari $75 \%$ Penyakit jantung terjadi di Negara berkembang seperti Indonesia. Data RISKESDAS (2018) menunjukkan bahwa sebesar 1,5\% atau 15 dari 1000 penduduk Indonesia menderita penyakit jantung koroner. Prevalensi jantung pada penduduk semua umur menurut provinsi tahun 2018 Kaltara $2,2 \%$, Jateng $1,7 \%$, NTT $0,7 \%$. Penderita jantung dengan rentang rerata umur 25-35 tahun terjadi komplikasi jantung. (RISKESDAS,2018). Masalah jantung membutuhkan penegakan diagnosis dengan pemeriksaan penunjang salah satunya dengan Elektrokardiogram (EKG).

Berdasarkan hasil wawancara terhadap pasien yang akan dilakukan EKG muncul rasa malu atau kurang nyaman ketika pemasangan EKG terutama pasien perempuan karena daerah dada dibuka. Meskipun tindakan perekaman EKG sudah ditutup dengan tirai untuk menjaga privasi pasien, namun masih menimbulkan perasaan kurang nyaman dengan prosedur tindakan yang seperti biasanya.

Prinsip memperbaiki rasa nyaman yang jauh lebih baik dalam pemeriksaan EKG dengan penggunaan aplikasi desain privasi baju EKG merupakan suatu inovasi dalam memperbaiki standar prosedur operasional (SPO)yang dapat digunakan sebagai upaya yang berkaitan proteksi daerah privasi pasien di rumah sakit. Aplikasi ini menjadi alat baru untuk mengatasi masalah yang timbul akibat terganggunya hak privasi sehingga menimbulkan kurang kenyamanan pasien.

Sejumlah penelitian telah melaporkan peran pemberian hak dalam menjaga privasi pasien seperti standar prosedur operasional (SPO) pemasangan EKG sesuai gender selama di rumah sakit disesuaikan dengan jenis kelamin perawat dan pasien. Penyesuaian gender ini ditujukan untuk memberikan tingkat kenyamanan sehingga tidak mengganggu hasil yang keluar dari mesin EKG. Detak jantung antara orang cemas dengan nyaman pasti akan memberikan hasil berbeda.

Perekaman EKG yang valid dipengaruhi oleh banyak faktor, salah satunya dipengaruhi oleh kecemasan pasien. Kecemasan sendiri dipengaruhi oleh ketidaknyamanan baik perasaan risih maupun malu. Baju ANT-VGAR dibuat sesuai dengan elektroda yang akan dipasang di dada, V1-V6, lubang yang dibuat pada baju disesuaikan dengan ukuran tubuh dan lokasi penempatan elektroda pada setiap titik interkosta. Penggunaan baju ini diharapkan tidak hanya mengubah kebiasaan membuka area dada saat pemeriksaan EKG tetapi mampu membuat suasana tenang dan nyaman dan terbina hubungan antara perawat dan pasien. Suasana senang dan aman nyaman pada pasien ini diharapkan dapat mempengaruhi hasil perekaman EKG secara valid. Penelitian ini bertujuan untuk mengetahui pengaruh baju ANT-VGAR terhadap rasa nyman pasien yang akan dilakukan pemeriksaan EKG

\section{METODE}

Desain penelitian menggunakan quasy experiment dengan pendekatan intact group comparison. Penelitian ini dilakukan di RS PKU Muhammadiyah Gubug. Sampel penelitian ini adalah pasien yang dilakukan pemeriksaan EKG dengan teknik purposive sampling sejumlah 30 responden. Responden terdiri dari dua kelompok yaitu 15 responden pada kelompok intervensi dengan pemberian Baju ANT-VGAR dan 15 responden pada kelompok kontrol menggunakan tirai sesuai pemeriksaan di rumah sakit. Responden diukur rasa nyamannya setelah dilakukan pemeriksaan EKG pada kedua kelompok. Analisis data penelitian menggunakan Man whitney untuk mengetahui perbedaan rerata rasa nyaman antara kelompok intervensi dengan kelompok kontrol. Kriteria inklusi pada penelitian ini 
adalah pasien berusia 20-45 tahun, mampu berkomunikasi, tidak terdapat gangguan panca indra (penglihatan), jenis kelamin pasien perempuan. Instrumen yang digunakan pada penelitian ini adalah Standar Prosedur Operasional (SPO) Baju ANT-VGAR dan kuisioner rasa nyaman yang dbuat oleh peneliti dan telah dilakukan uji validitas dan reliabilitas dengan hasil validitas sebesar 0,931-0,939 dan reliabilitas 0,941 . Penelitian ini telah memenuhi uji etik dengan nomor 17/KH.KEPK/KT/I/2020.

\section{HASIL}

Tabel1.Rerata rasa nyaman pada pemasangan EKG menggunakan baju ANT-VGAR (kelompok Intervensi) dan menggunakan tirai (kelompok kontrol).

\begin{tabular}{lccccc}
\hline $\begin{array}{l}\text { Rasa } \\
\text { nyaman }\end{array}$ & $\mathrm{n}$ & Mean & Median & Sd & $\begin{array}{l}\text { Min- } \\
\text { Max }\end{array}$ \\
\hline $\begin{array}{l}\text { Kel. } \\
\text { Intervensi }\end{array}$ & 15 & 22,53 & 23 & 1,72 & $18-24$ \\
\hline $\begin{array}{l}\text { Kel. } \\
\text { Kontrol }\end{array}$ & 15 & 19,86 & 20 & 3,35 & $13-24$ \\
\hline
\end{tabular}

Hasil penelitian didapatkan nilai rata-rata rasa nyaman pasien yang menggunakan bajuANTVGAR sebesar 22,53, median 23, dengan standart deviasi1,72, nilai terendah 18 dan nilai tertinggi 24 . Nilai rata-rata rasa nyaman pasien yang menggunakan tirai sebesar 19,86, median 20, dengan standart deviasi 3,35, nilai terendah 13 dan nilai tertinggi 24.

Hasil Uji normalitas menggunakan Shapiro Wilk didapatkan rasa nyaman kelompok intervensi dengan $p$ value : 0,006 dan kelompok kontrol $p$ value 0,379 sehingga analisis menggunakan uji Man Whitney. Hasil uji analisis dapat dilihat pada tabel 2.

Tabel2. Pengaruh baju ANT-VGAR terhadap rasa nyaman pasien pada pemeriksaan EKG $(n=30)$

\begin{tabular}{llll}
\hline Rasa nyaman & & $\begin{array}{l}\text { Mean } \\
\text { rank }\end{array}$ & P value \\
\hline Kelompok & Kontrol & 11,90 & 0,023 \\
\cline { 2 - 3 } & Intervensi & 19,10 & \\
\hline
\end{tabular}

Berdasarkan tabel 2 diketahui bahwa ada pengaruh bajuANT-VGAR terhadap rasa nyaman pasien pada pemeriksaan EKG ( $p$ value : 0,023 )

\section{PEMBAHASAN}

Hasil penelitian didapatkan penggunaan baju ANT-VGAR pada responden dengan pemeriksaan EKG memiliki nilai rasa nyaman 22,53 sedangkan pada responden yang menggunakan tirai 19,86. Data tersebut menunjukkan rasa nyaman pasien yang menggunakan baju ANT-VGAR memiliki rasa nyaman yang lebih tinggi dibandingkan dengan responden yang menggunakan tirai. Responden yang menggunakan tirai meskipun area sekitar ditutup namun area dada pasien terbuka sedangkan pada responden yang menggunakan baju ANT-VGAR area dada rsponden tetap tertutup pada saat perekaman EKG. Baju ANT-VGAR di desain dengan membuat lubang baju tepat pada titik intercosta untuk memasang elektroda elektrokardiogram (EKG) dengan menekankan area privasipasien yang digunakan saat perekaman EKG dan meningkatkan rasa nyaman.

Hasil penelitian ini didukung oleh penelitian Mohammad Henri (2018) bahwa perawat harus selalu menjaga privasi pasien dan selalu meminta izin (inform concent) sebelum melakukan tindakan. Area dada pasien yang terbuka saat perekaman EKG mengakibatkan pasien tidak nyaman dan dapat berpengaruh terhadap hasil pemeriksaan EKG. Penggunaan baju ANT-VGAR dapat menutup area dada saat perekaman EKG, sehingga dapat meningkatkan rasa nyaman pasien.

Beberapa aspek yang mempengaruhi kenyamanan/rasa nyaman antara lain : aspek fisik yang berhubungan dengan sensasi tubuh, aspek sosial berhuungan dengan hubungan interpersonal, keluarga dan sosial, aspek psikospiritual berhubungan dengan kewaspadaan internal dalam diri sendiri yang meliputi harha diri, seksualitas dan makna kehidupan.dan aspek fisik dengan ruangan Aspek lingkungan berhubungan dengan latar bealkang pengalaman eksternal seperti cahaya, bunyi, temperatur, warna dan unsur 
lainnya (Kalcoba, 1992 dalam potter \& Perry).Pada penelitian ini rasa nyaman pasien juga dipengaruhi oleh beberapa aspek tersebut seperti responden merasakan kedinginan saat baju responden dibuka untuk perekaman EKG,ada juga responden yang gemeteran dan jantungnya berdebar keras dikarenakan ada yang baru pertama dilakukan pemeriksaan EKG. Aspek social berhubungan dengan hubungan interpersonal dengan dilakukanya pemeriksaan EKG dengan lawan jenis yang mengakibatkan responden merasa malu area privasinya dilihat dan ada juga responden yang menolak. Aspek psikospiritual, berhubungan dengan kewaspadaan internal responden merasa khawatir dan takut dilecehkan saat pemeriksaan EKG yang dilakukan oleh lawan jenis, dan ada juga responden yang cemas area privasinya dipegang. Aspek lingkungan, dari aspek lingkungan dengan ditutupnya tirai dan baju ANT-VGAR untuk menutupi area privasi responden dari ruangan sekitarnya.

Hasil penelitian didapatkan ada pengaruh baju ANT-VGAR terhadap rasa nyaman pasien pada perekaman EKG. Perbedaan rasa nyaman antara kelompok intervensi dengan kelompok kontrol terhadap rasa nyaman pasien pada perekaman EKG ( $p$ value 0,023 ). Kelompok intervensi memiliki rasa nyaman lebih tinggi dan dari hasil kuesioner yang berisi empat aspek kenyaman pasien saat perekaman EKG yang diberikan pada kelompok eksperimen sebagian besar responden menjawab nyaman.

Penelitian ini didukung hasil penelitian bahwa rasa nyaman pasien dipengaruhi oleh empat aspek kenyamanan yaitu aspek fisik, sosial, psikospiritual dan lingkungan. Hasil penelitian ini didukung juga oleh penelitian Meri S. (2018) bahwa kenyamanan dan Kepuasan Pasien dalam Proses Interaksi Pelayanan Keperawatan di RSUD Petala Bumi menunjukkan bahwa pasien di Instalasi Rawat Inap, sebagian besar berada pada kategori Nyaman (52,03\%) dan sebagian besar pasien berada pada kategori puas (72,36\%) dalam proses interaksi pelayanan keperawatan.

\section{KESIMPULAN DAN SARAN}

Penggunaan baju ANT-VGAR dapat meningkatkan rasa nyaman pasien pada pemeriksaan EKG. Baju ANT-VGAR ini dapat menutup area dada yang terbuka saat perekaman EKG, sehingga lebih menjaga privasi pasien selain pengaturan privasi lingkungan pasien. Penggunaan baju ini diharapkan dapat digunakan pada pasien yang akan dilakukan perekaman EKG sehingga meningkatkan kenyamanan pasien dan peningkatan pelayanan oleh profesi keperawatan. Penggunaan baju ANT-VGAR dapat dilakukan penelitian lebih lanjut terkait penggunaan bahan yang dipakai dalam baju ANT-VGAR.

\section{REFERENSI}

Albert, N. M., Wocial, L., Meyer, K.H., Na, J, \&Trochelman, K. (2008).Impact nurses uniforms on patient and family perceptions of nurse professionalism.Applied Nursing Research, 2, 181-190.

Dahlan, M. Sopiyudin. (2010). Statistik Untuk Kedokteran dan Kesehatan. Deskriptif Bivariat, dan Multivariat. Dilengkapi dengan menggunakan SPSS.Jakarta :Salemba Medika.

DinkesJateng. (2018). Profil Kesehatan Provinsi JatengTahun 2018. Semarang; Dinas Kesehatan Provinsi Jawa Tengah.

Ilmiasih , R. (2012). Pengaruh Seragam Perawat :Rompi Bergambar Terhadap Kecemasan Anak Pra Sekolah Akibat Hospitalisasi. Jakarta : FIK UI

Kemenkes RI. 2018. RISKESDAS 2018. Jakarta. Badan Penelitian dan Pengembangan Kemenkes RI.

Kemenkes RI.(2018).Jantung dan Pembuluh Darah Kita.www.depkes.go.id.

Meri S.(2018). Kenyamanan dan Kepuasan Pasien Dalam Proses Interaksi Pelayanan Keperawatan di RSUD Petala Bumi.

Mohammad Henri. (2018). Mutu Dimensi Jaminan Pelayanan Kesehatan Dalam Peningkatan Kepuasan pelanggan di RSUD Dr. H. Koesnadi Bondowoso. 
Muttaqien, F. (2010). EKG Funny. Yogyakarta :Pustaka Avicenna.

Notoatmodjo, Soekidjo. Metodologi Penelitian Kesehatan. Cetakan kedua. Jakarta :Rineka Cipta.2012
Potter, P.A., \& Perry, A.G. (2010).Fundamental of Nursing: Concepts, Process and Practice. Edisi 4. Alih bahasa: Renata, K. et al. Jakarta: Penerbit Buku Kedokteran EGC

World Health Organization (WHO).(2018). Global Cardiovaskuler Report 2018. Switzerland. 